\title{
On the Construction of Self Identity in Invisible Man
}

\author{
Gaixia Wang ${ }^{1, a}$ \\ ${ }^{1}$ School of Foreign Languages, Neijiang Normal University, Neijiang 641199, China \\ a 735669253 @qq.com
}

Keywords: Ralph Ellison, Invisible Man, white culture, black culture, identity

\begin{abstract}
In Ralph Ellison's Invisible Man, the construction of the narrator's identity is actually closely related to how the narrator resolve the conflict between black culture and white culture. The narrator's indulgence in white culture reduces him to the fate of invisibility while his return to black culture paves the way for the construction of his cultural identity.
\end{abstract}

\section{Introduction}

The conflict of black and white culture is actually closely related to how the narrator resolves the conflict between black culture and white culture. The narrator's indulgence in white culture reduces him to the fate of invisibility while his return to black culture paves the way for the construction of his cultural identity. The narrator has been painstaking in the construction of self identity. From the indulgence in the white culture to the awakening from it, then to the incorporation into the black culture, the narrator finally succeeds in the construction of identity.

\section{Indulgence in White Culture}

From the Bible, we could know that when God creates the world, he first gives a name to what is created and hence all things on earth have names and become meaningful. "The unity and uniqueness of the name is not only a mark of the unity and uniqueness of the person, but actually constitutes it: the name is what first makes man an individual.” [1] Therefore, the nameless narrator is destined to be a man of no identity.

The narrator's indulgence in conformity is the primary reason why he is depraved of identity. On his graduation day he delivered an oration, showing "humility was the secret, indeed, the very essence of progress." [2] In order to gain another chance of speech delivered at a gathering of the leading white citizens, he participates in the boxing with other black boys with blindfolds on their eyes, and is subject to the humiliation in the coin grabbing game. In the end, he receives another prize, a brief case loaded with an official-looking document, namely, a scholarship to the state college for Negroes. Then he comes into tears with wild excitement. After entering the college, the narrator goes on with his conformity and wishes to become people like Dr Bledsoe, a black president of high status and huge wealth.

However, he doesn't realize the embarrassment of the dual identities in American society. What he's being striving for is at a price of the dignity, while the American Dream lies too far beyond the reach of the black. Actually, the narrator is not without the enlightenment of how to construct his own identity. The last words of his grandfather is inspiring for him to seek his identity, which is a case in point.

As a wise man, his grandfather symbolizes the weather-beaten history of the black people. His father's last words reveal what is true of black Americans. "But our life is a war and I have been a traitor all my born days, a spy in the enemy's country ever since I give up my gun back in the Reconstruction. Live with your head in the lion's mouth. I want you to overcome 'em with to death and destruction, let 'em swoller you till they omit or bust wide open." [2] But the narrator is completely bewildered by his father's last words. During the night after the acceptance of the prize, the narrator dreams that his good father laughs at him and the letter reads "Keep This Negger-Boy Running." [2] If he had fathomed the implication of his grandfather's words, he wouldn't have regarded his grandfather's mock as meaningless. Therefore, even with his grandfather's sincere 
enlightenment, the narrator still indulges himself in conformity rather than rebellion against the prejudice and discrimination of the white Americans.

What is more, the veteran stresses the fact that Mr. Norton is "only a man" and should not be treated as if he were some god, the protagonist remains skeptical. The protagonist sticks to his own view of racial relationship and refuses to accept the veteran's offer of the solution to invisibility, as his monologue reveals: "I wanted to tell him that Mr. Norton was much more than that, that he was a rich man and in my charge; but the very idea that I was responsible for him was too much for me to put into words". [2] The protagonist unconsciously denies what the vet is saying. The only thing he cares about is how to please Mr. Norton and leaves this Golden Day as quickly as possible. Thus, "the narrator's genuflective attitude toward Mr. Norton seems less like simple stupidity and more like the response of one who has learned his 'lessons' well". [3]

Indulged in the conformity, the narrator proceeds to appreciate the power of the conformity held by Doctor Bledsoe. The narrator appreciates Dr. Bledsoe's wealth and status, but never reflects on how Dr. Bledson holds on to it. Dr. Bledsoe's character is worthy of some words. In front of the white people, Dr. Bledsoe tends to be servile. While to the black, he is two-faced and overriding. Dr. Bledsoe became the successor of the founder of the college who had wielded even more super power over the school. Just as Mr. Norton says, "But your great Founder had more than that, he had tens of thousands of lives upon his actions... in a way, he had the power of a king." [2] Dr. Bledsoe pleads the breach of the regulation as the excuse for the narrator's expulsion from the school. On the surface, he promised the narrator that the narrator would come back as a paying student. But beneath his hypocritical manner, Dr. Bledsoe writes seven sealed letters to stifle the narrator's opportunity because "one for whom we held great expectation has gone grievously astray, and who in his fall threatens to upset certain delicate relationships between certain interested individuals and the school." [2] To Dr. Bledsoe, his power comes from his blind conformity to the white American's standard, while his soul and dignity is betrayed as in the contract of Dr. Faustus and Lucifer. It can be said that Dr. Bledsoe has been assimilated by white culture, hence no cultural identity. In this sense, the narrator's blind worship for the president is perilous, indicative of his blind conviction in the power of conformity.

Furthermore, the narrator's aversion to black culture aggravates his alienation from cultural identity. The black culture is closely related to the pursuit of identity, and Ellison's characterization of Jim Trueblood is a good example. Trueblood relieves himself from the Blues in which he comforts his own guilty heart gradually, which proves to be effective in soothing it--- a returning to his black culture and a identification of himself. Blues, accompanied with other music types like jazz, spiritual and ragtime, coveys the black people's own history, life, emotion and thinking. Besides, it's of strong color of black culture, representing the existence of not only the black people but also the black culture. Therefore, it's the strong voice of the black people in the heart as well as the weapon against racial discrimination. As Selma Fraiberg notes, Trueblood refuses to "hide behind the cowardly deceptions that cloak sin; he faces the truth within himself". [4] It is Trueblood's own understanding of himself and black culture, as in his tale, that makes the meaning of his life, not that of those white people who ridicule him nor that of blacks who see him as disgrace to the race.

It is a pity that the narrator is too thrilled with the incest narrative of Trueblood to perceive the importance of black culture to blacks. The intrinsic difference between Trueblood and the narrator is that the former seeks self identity from the massive history and the lost black culture while the narrator consciously secluded himself from black culture by conforming to the white culture. In this sense, the narrator's aversion to the black culture prevents him from cultural identity.

\section{The Awakening from the Lost Soul}

After arriving in New York, the narrator shows hesitation toward the return to black culture, which is indicative of his awakening. As he thinks to himself, "I have never seen so many black people against a background of brick-building...And there were white drivers in the traffic who obeyed his signals as though it was the most natural thing in the world." [2] However, when the 
counterman comes over and offers him the specialist, the favorite food of the black people, he contemplates over his south identity and then averts to it. Naturally, he gives an indifferent attitude to the counterman's offer. Instead, he pretends to belong to the white Americans by asking for “orange juice, toast and coffee." [2] The narrator deliberately desalts his identity as a black young man when the fear of his own real self identity comes over to him. At least, he realizes his self identity, but still dare not to admit it in the public.

Injured by the explosion in the plant, the narrator loses his consciousness but comes to realize his situation through black culture. When he awakes in hospital, he is interrogated by the white doctors with the question "Who was Buckeye the rabbit?" [2] It suddenly throws the narrator to the thought that his own fate, like the rabbit in the legend, is subject to the game of tease and chase in the woods. At the sound of the song lyric "shake it, shake it... break it, break it", the narrator comes to realize that he is part of the black culture. [2] Though greatly annoyed, he does acknowledge his original identity. Then he becomes "no longer afraid." [2]

In Harlem, the narrator immerses himself in the black culture. Different from the selfish and indifferent white people, the black woman Mary takes care of this young man heart and soul. Mary represents a force, and even a signal of the black culture. Beneath narrator's thankfulness to Mary is his gratitude to his return to the black culture. Differently, he returns to the yam to cherish a sense of belonging to the black culture. He has no need to flatter others or repress his own true feelings. "Give me two more" seems to be a declaration that he has returned to the black culture in thought.[2]

After the immersion in black culture, the narrator begins to applaud the black culture in action. When an old couple being evicted prayed in the house, he witnessed "a pair of crudely carved and polished bones, 'knocking bones,' used to accompany music at country dances, used in black-face minstrels", which reminded him of the remote places and passed days he once cherished. [2] Then the narrator takes action to disrupt the eviction to help his black people. The narrator, by giving a speech, actually mobilizes the fury of the public to help the couple. In so doing, the narrator applauds the black culture in action.

\section{The Incorporation into the Black Culture}

After the eviction event, the narrator begins to take further actions to preserve his return to the black culture in action. However, his actions are only out of a blind flash of insight.

James Joyce defines flash of insight as a momentary spiritual phenomenon, through which one can attain poignant understanding and cognition about himself or other things around him. The leap from one thing to its inartistic quality is on the basis of the enough accumulation of quantitative facts and experience. Flash of insight premises enough corresponding cognition through facts. Under such circumstance, when one is stimulated by one particular thing, he can attain a flash of insight about the whole matter.

The narrator's further action refers to his speech delivery for the Brotherhood like what Booker T. Washington does to highlight the cause of the black people.

But the Brotherhood only supplies him as a tool of declaration of Brotherhood's own routine, depraving him of his own thoughts and other rights. A slight error would lead to the warning from the Brotherhood. In this case, the narrator fails to construct his identity because his passion for the identity construction through black culture is utilized by the wickedness of the Brotherhood. In this sense, the narrators' flash of insight turns out to be blind, but instructive for his later genuine flash of insight.

In the novel, brother Tarp particularly hangs the portrait of Frederick Douglass on the wall. Later he gives the narrator the chain which he has kept for over nineteen years. Douglass can be regarded as a famous black American writer in the 19th century who believed in racial equality and committed himself to this ideal by initiating "slave narrative novels". Chain symbolizes the slavery history of the black people. The portrait and the chain, on the one hand, enlighten the narrator on the outlet for the black's fate, and on the other hand, show that the narrator has been ready for the complete return to black culture. As to Brother Clifton, Ellison takes pains to subvert the 
stereotyped black people who are of meager education, brutality and cruelty or who are stupid or tame slaves. When Clifton detects the motive of the Brotherhood, he lets out of his protest intensively by selling the doll symbolizing and publicizing the bitter situation of the black people. It's his sudden death that prompts the narrator's genuine flash of insight. He, like Clifton, is repeatedly utilized by the Brotherhood to achieve its own political aim---keep themselves in charge of the black in the community. As he says to himself, "I always tried to go in everyone's way but my own.” [2] At Clifton's funeral, he is thrilled with the song lyrics ---“"There’s many a thousand gone”, which was sung by the procession attending Clifton's funeral. [2] He joined in the procession and sang the song characteristic of the "the past of the campus and still earlier part of home"---“slave-borne words".[2]

Meanwhile, the diverse role attributed to Rinehart dramatically falls upon him and lets he see through the disorder and riot in American society. Finally, he confines himself to the cellar and "burns every paper in the briefcase". [2] At last, he fathoms the essence of his grandfather's last words and frankly faces up to the miserable situation.

Though in the mainstream of the white American's culture, the narrator is invisible, the narrator believes it not to be an eternal plight for him because he believes that "even an invisible man has a socially responsible role to play." [2] Then in the end, he said that he must "shake off the old skin”. [2]

Then what does the "old skin" really mean? It is absolutely the past including the practice of conformity, the blind belief in the power of conformity, and the blind flash of insight into the realization of his own self identity. However, his construction of identity is in the form of either laying questions for others or waiting for others' recognition. He would both observe conformity for the white Americans and work for Brotherhood blindly. But he never believes in himself.

By saying such words, the narrator bids farewell to the past completely and holds confidence in the root of black culture because he believes in the relations of invisibility and blackness. If the black people were to be invisible, why should they be in a flutter of questing for some identity they are not entitled to? Blackness associated with invisibility is the real self identity not to be feared by the black people.

In essence, the narrator finally fathoms that he fears not the invisibility but the fear of invisibility. In other words, he fears not the blackness but the fear created by him at the thought of the blackness. With such insight, he preserves his own self identity.

\section{Summary}

Actually, Ellison pushes forward the theme of black identity in black literature. The black writes after Ellison commit themselves to resolving the problem of the black identity in cultural context.

In 1976, Alex Haley published his novel Roots which aroused great attention in the literary circle. The theme of the novel is that the black American should not forget their root in Africa, the pains and persecutions their forefather has suffered under the slavery system. Morris, the most brilliant writer after Ellison, endeavors to seek the root of the black culture in the white culture-dominated society in his writings and arouses the black's cultural consciousness. Her novels reflect the wavering of the black youth between incorporating into the mainstream white culture and preserving the black's traditional culture. The most sparking point in Invisible Man is the reasonable thinking about the black's social plight and ideological weakness. Thus, the road to the self construction has become more powerful and inspiring since then.

\section{References}

[1] C. Ernst. Language and Myth, Dover Publications Inc., New York, 1984, pp. 5.

[2] R. W. Ellison, Invisible Man, Foreign Language and Research Press, Beijing, 2000. 
[3] J. Eichelberger, Prophets of Recognition: Ideology and the Individual in novels by Ralph Ellison, Toni Morrison, Saul Bellow, and Eudora Welty, Louisiana State University Press, Baton Rouge, 1999, pp. 31.

[4] S. Frailberg, Two Modern Incest Heroes, Partisan Review 28(1961) 659. 